\title{
The Impact of Nitrogen and Phosphorus Dynamics on the Kinneret Phytoplankton: II: Chlorophyta, Cyanophyta, Diatoms and Peridinium
}

\author{
Moshe Gophen \\ Migal-Galilee Scientific Research Institute, Kiryat Shmona, Israel \\ Email: Gophen@Migal.org.il
}

How to cite this paper: Gophen, M. (2017) The Impact of Nitrogen and Phosphorus Dynamics on the Kinneret Phytoplankton: II: Chlorophyta, Cyanophyta, Diatoms and Peridinium. Open Journal of Modern Hydrology, 7, 298-313.

https://doi.org/10.4236/ojmh.2017.74017

Received: August 14, 2017

Accepted: October 22, 2017

Published: October 26, 2017

Copyright $\odot 2017$ by author and Scientific Research Publishing Inc. This work is licensed under the Creative Commons Attribution International License (CC BY 4.0).

http://creativecommons.org/licenses/by/4.0/

\begin{abstract}
Lake Kinneret long-term data of the epilimnetic concentrations (ppm) and loads (tones) of the total Nitrogen (TN), total Phosphorus (TP), total inorganic Nitrogen (TIN), total Dissolved Phosphorus (TDP), Phytoplankton groups' biomass, water level (WL) and Jordan River Discharge were analyzed. Previously collected data compiled aimed at an insight into the causative background for the modification of Phytoplankton community change. The study was carried out by searching for relations between algal groups' densities and nutrient conditions in the Epilimnion by the use of statistical methods (Simple and Fractional Polynomial Regressions). The study is aimed at analyzing the relations between algal biomass and nutrient contents. It was found that Nitrogen decline and slight increase of phosphorus were followed by Peridinium (Photo 1) decline and biomass increase of non-peridinium algae. It is suggested that nitrogen supply for algal growth is mostly from external sources, and the reduction of nitrogen in the epilimnion was caused by external removal. Contrary to nitrogen, phosphorus sourcing is only partly external (dust deposition, drainage basin) and mostly internal through double channels: Microbial mineralization of bottom sediments and Peridinium cysts mediation. The resulted complexity of the Kinneret ecosystem structure is nitrogen limitation, and enhancement of Non-peridinium algal growth, mostly Cyanobacteria.
\end{abstract}

\section{Keywords}

Chlorophyta, Diatoms, Cyanobacteria, Nitrogen, Phosphorus, Kinneret

\section{Introduction}

During the recent 50 years, Lake Kinneret and its drainage basin Ecosystems has 
undergone significant changes. Climate change of temperature elevation, decline of precipitation, as well as innovated management of the drainage basin caused suppression of Lake inputs of Nitrogen. The Kinneret limnological trait shifted from phosphorus to nitrogen limitation accompanied by modifications of the phytoplankton population structure. The routine bloom forming Peridinium (Photo 1) in late winter was replaced by enhancements of Cyanophytes, Chlorophytes and Diatoms [1]. In the first part of the study ("I:Peridinium Cyanophyta alternate"), the impact of total nitrogen (TN) and total phosphorus (TP) on Peridinium replacement by Cyanophyta was analyzed. Here, a study of the enhancement of the non-Peridinium algal groups in relation to the "Total" and "Bio-available" (dissolved) species of nitrogen and phosphorus contents is presented.

Field observations i.e. routinely monitored data-base, are crucial in Ecological sciences. This information should be integrated with compatible experimental information. Moreover, routinely collected field data might be therefore significant for the formulations of conclusive confirmations of previously hypothesized conjectures. A famous Anthropologist, E. Adamson Hoebel [2] stated that the studies carried out and published by M. Mead [3] might be a classical example of how field observation is equally valued to experimental observations. The present paper evaluates field data set collected routinely during long-term period. The conclusive conjectures and/or hypothesis could not be implemented without the contribution of the experimental information such as chemical composition of lake water and algal matter. The combination of both experimental results and field-data are therefore suitable for future predictions given later. The impact of nitrogen and phosphorus on phytoplankton growth was widely documented [4] by many authors. The unique nutrient limitation trait of

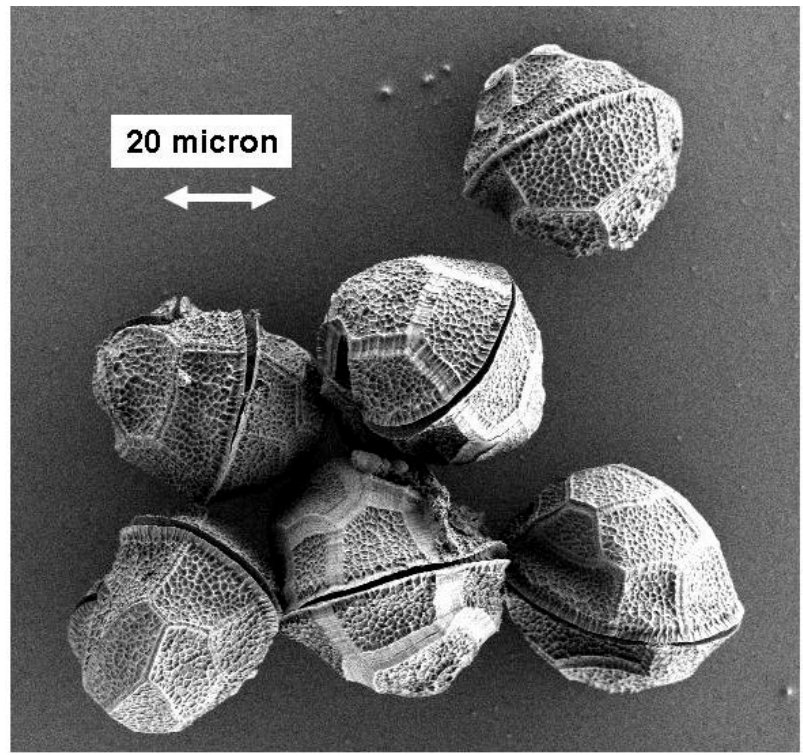

Photo 1. SEM (Scanning Electron Microscope) photo of Peridinium cells from Lake Kinneret: By courtesy of Dr. Boris Fichtman, Bar-Ilan University, Medical School (scale is given). 
nitrogen and phosphorus, solely and in relation, was intensively studied as well, among others [5] [6] [7]. In the present study, the long term field data record is tentatively aimed at its impact on phytoplankton distribution. An attempt to give an insight into the paradigm of phytoplankton-nutrient relations in Lake Kinneret is presented. The compositional modifications of Phytoplankton assemblages in Lake Kinneret were previously studied. But the causation of nutrient trait dominance, presented here, is an innovative insight. Previous studies were not strictly focused on nutritional conditions as major impact which is tentatively present paper.

\section{Materials and Methods}

The following long-term (randomly taken: 1969-2001) information of monthly averages (weekly and bi-weekly samples) taken from Kinneret Limnological Laboratory Data Base [8]. The monthly means were condensed into annual averages in order to allocate the multiannual trend of relations. The following parameters were selected in the present study: phytoplankton (sampling methods are given in [1] [8]), (Peridinium, Chlorophyta, diatoms and Cyanophyta) biomass $\left(\mathrm{g}(\mathrm{ww}) / \mathrm{m}^{2}\right)$, total nitrogen $(\mathrm{TN})$, total phosphorus $(\mathrm{TP})$, total inorganic nitrogen (TIN), total dissolved phosphorus (TDP) as concentration (ppm) or total load in the Epilimnion (tonnes in the Epilimnion), N/P mass (w/w) ratio, water level (WL; mbsl) and Jordan River Discharge (Cubic Meter per Second). Two statistical methods were used: Simple Linear Regression, and the Nonlinear Fractional Polynomial Regression (STATA 9.1) with given $\mathrm{r}^{2}$ (correlation coefficient).

All monthly mean values were compiled as annual averages on which statistical tests were carried out. Phytoplankton data is based on samples collected in Station A and chemical information is due to averaged values of samples collected in 7 stations throughout the entire lake (A, C, D, F, G, H, K) [9].

\section{Results}

Annual Grand total means of TN, TP, TIN and TDP [8] have indicated that TIN comprises $30 \%$ of TN and TDP comprises $26 \%$ of TP. Figure 1 and Figure 2 indicates moderate stability of seasonal relations between the total and bio-available dissolved species of nitrogen (Figure 1) and phosphorus (Figure 2). TN represent long-term decline (1991 and 1992 exceptionally due to heavy floods) of epilimnetic load but stable TIN load doesn't. Contrary to nitrogen, TP represent a slight increase but decline of TDP since mid-1980s. Fractional Polynomial Regression of the relations between epilimnetic loads of TDP (independent) and TIN (dependent) (Figure 3) indicates inverse relation when TDP was changed from 20 to 15 tonnes but positive-directly when TDP was changed below 15 tonnes.

Annual averages of total phytoplankton and Peridinium biomass $\left(\mathrm{g} / \mathrm{m}^{2}\right)$ shown in Figure 4 indicates a gradual decline of Peridinium since mid-1980s: 7 years with exceptional low biomass and 4 years with normal higher biomass but clear elevation of total phytoplankton biomass. Contrary to the Peridinium decline 


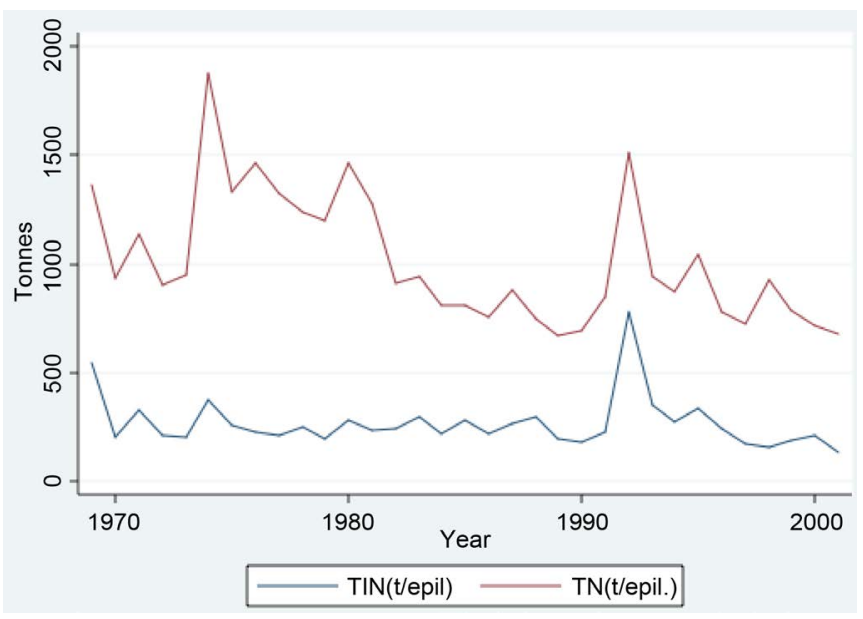

Figure 1. Annual (1969-2001) averages (t/Epilimnion) of Total Nitrogen (TN) and Total Inorganic Nitrogen (TIN).

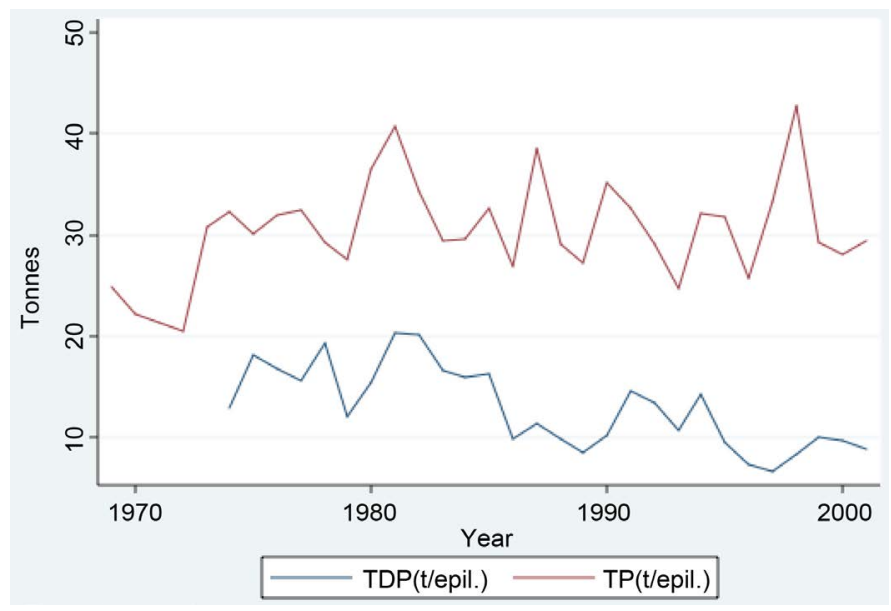

Figure 2. Annual (1969-2001) averages (t/Epilimnion) of Total Phosphorus (TP) and Total Dissolved Phosphorus (TDP).

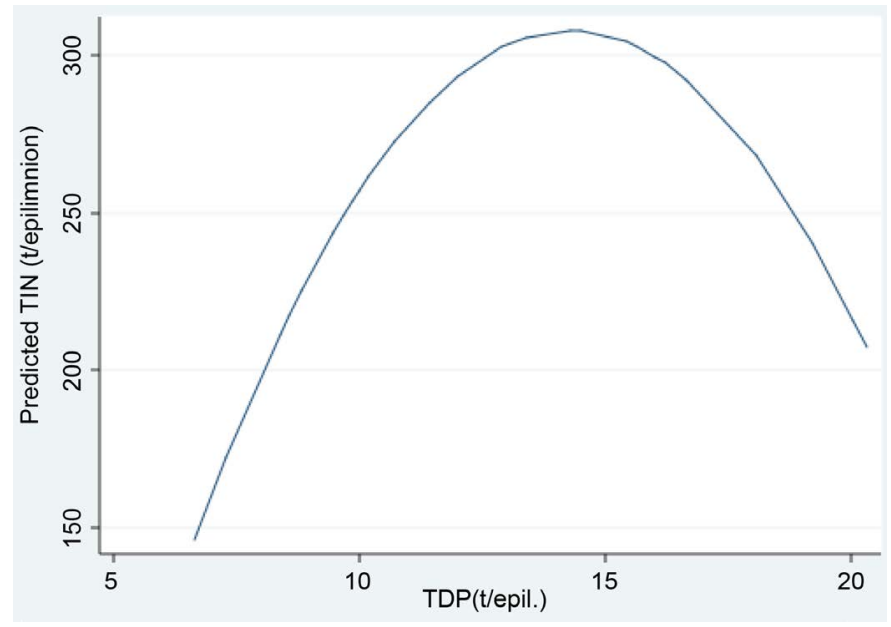

Figure 3. Fractional polynomial regression between Total Dissolved Phosphorus (TDP) (independent) and predicted Total Inorganic Nitrogen (TIN) epilimnetic loads during 1969-2001 (dependent). 


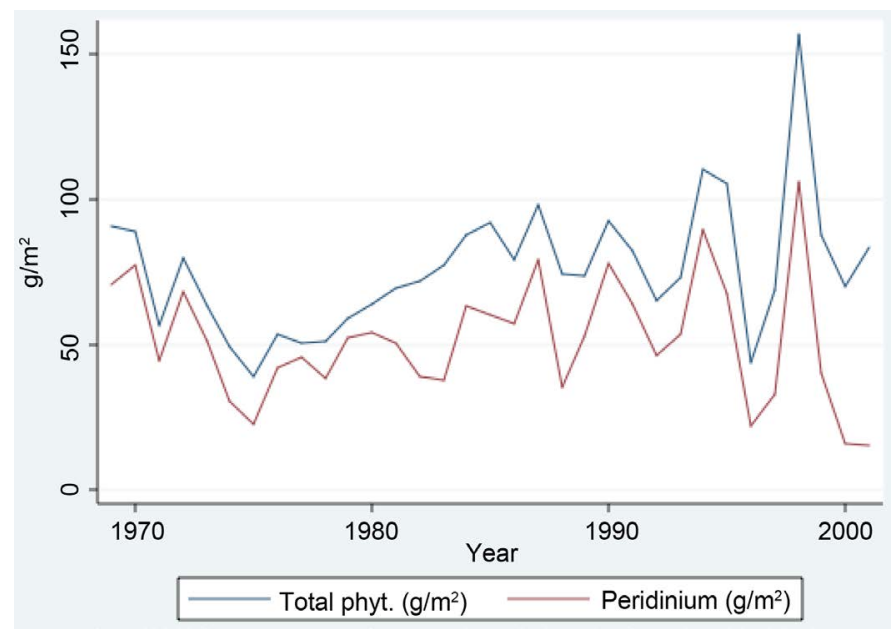

Figure 4. Temporal fluctuations of annual (1969-2001) means of peridinium and total phytoplankton Biomass $\left(\mathrm{g} / \mathrm{m}^{2}\right)$.

the Biomass of Chlorpphyta, Cyanophyta and diatoms biomass (Figure 5) represent a prominent increase. The partial replacement of Peridinium by non-Peridium algal (Chlorpphyta, Cyanophyta and diatoms) biomass is clearly defined by deepening of Secchi depths (Figure 6): from $3.2-3.1 \mathrm{~m}$ until mid-1980s to 3.2 - 3.5 later. The clear replacement of Peridinium by Cyanophyta is presented in Figure 7.

\subsection{Water Level and Phytoplankton Fluctuations}

The long-term record of WL fluctuation (Figure 8, Annual averages) indicates decline of annual means since early 1980s by $2.4 \mathrm{~m}$ (from 210 to $212.4 \mathrm{mbsl}$ ) in 2001. The decline of WL was prominently accompanied by decline of TDP (Figure 9) and TIN (Figure 10). Moreover, the decline of TIN below epilimnetic load of 200 tonnes was accompanied by abrupt increase of the biomass of Chlorophyta (Figure 11) and Cyanophyta (Figure 12).

\subsection{Nutrients-Phytoplankton Relationships}

Lower loads of TDP in the Epilimnion were accompanied by enhancement of the biomass of Chlorophyta and Cyanophyta (Figure 13 and Figure 14). Nonetheless, the decline of the concentration (ppm) of TP in the Epilimnion was accompanied by decline of the biomass of Chlorophyta, diatoms and Cyanophyta (Figures 15-17). Fractional Polynomial Regression between Peridinium as independent and epilimnetic TP load as dependent emphasize the mutual decline of Peridinium biomass $\left(\mathrm{g} / \mathrm{m}^{2}\right)$ and TP load (Figure 18). The nitrogen and phosphorus content (\%) in phytoplankton groups and in the epilimnetic loads (tones) is shown in Table 1.

The highest and the lowest content of nitrogen in Peridinium and Cyanophyta respectively are indicated. It is therefore concluded that nitrogen is a limiting growth factor for Peridinium cells and much less significant for Cyanobacteria. 


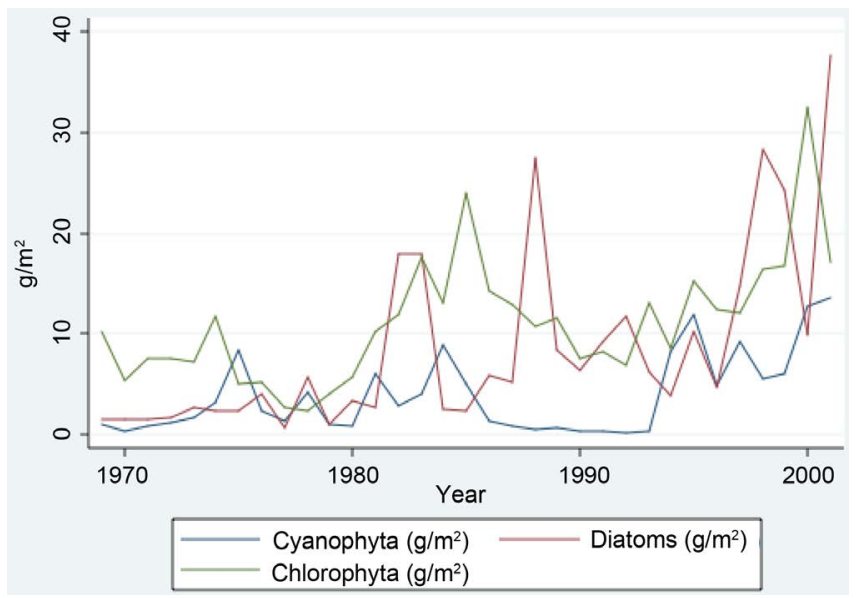

Figure 5. Temporal fluctuations of annual (1969-2001) means of cyanophyta, chlorophyta, and diatom biomass $\left(\mathrm{g} / \mathrm{m}^{2}\right)$.

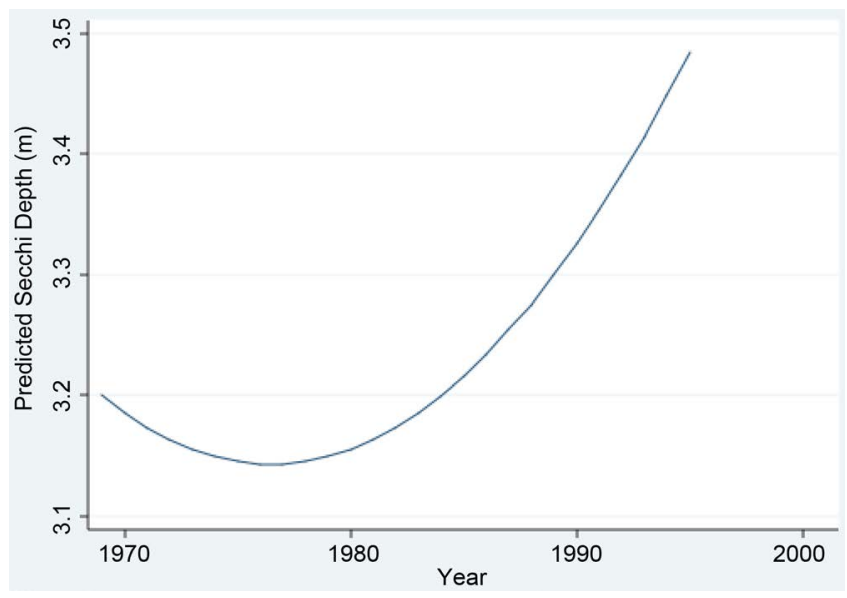

Figure 6. Temporal (1969-2001) fractional polynomial regression between years (independent) and annual means of predicted secchi depths (dependent).

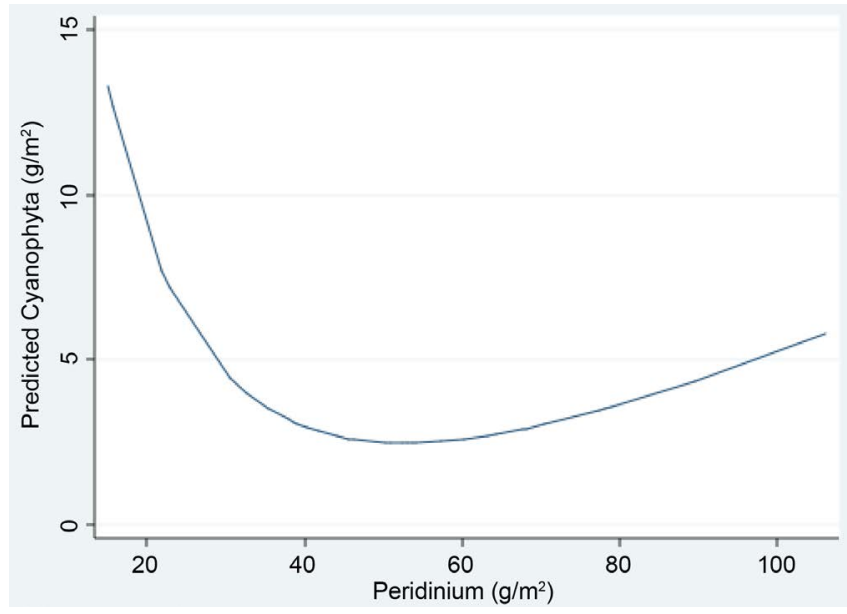

Figure 7. Fractional polynomial regression between annual (1969-2001) means of Peridinium ( $\left.\mathrm{g} / \mathrm{m}^{2}\right)$ (independent) and predicted Cyanophyta biomass $\left(\mathrm{g} / \mathrm{m}^{2}\right)$ (dependent). 


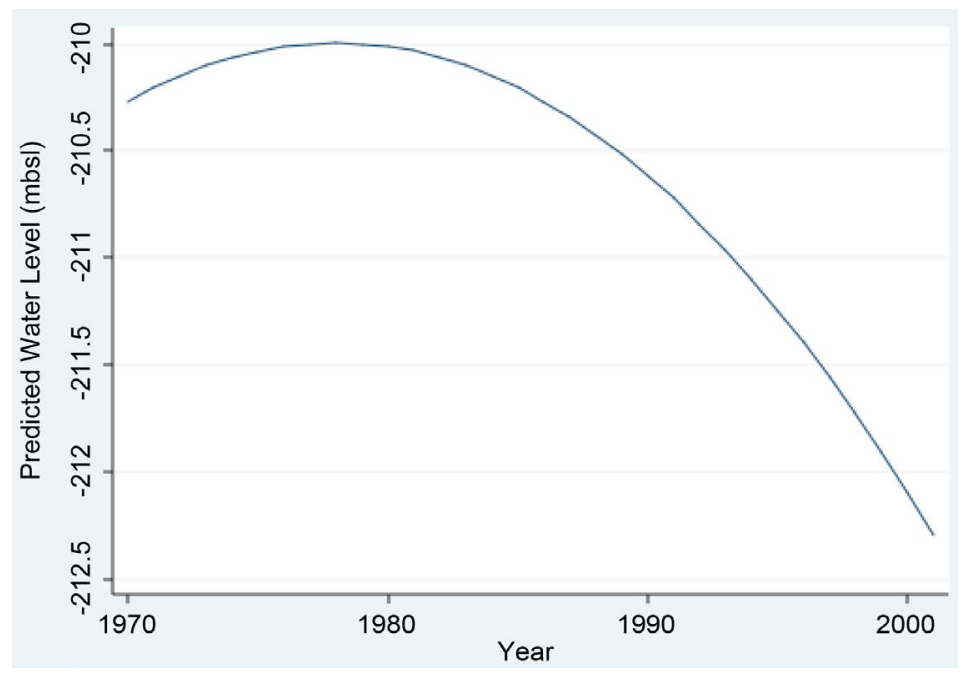

Figure 8. Temporal (1969-2001) fractional polynomial regression between years (independent) and predicted annual mean of water level (mbsl) (dependent).

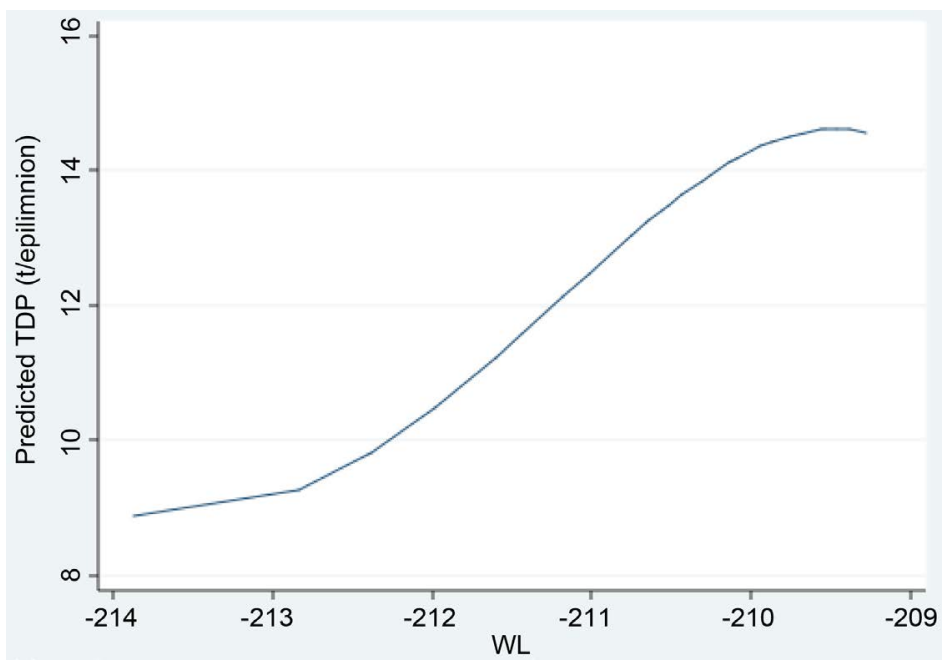

Figure 9. Fractional Polynomial regression between annual means of Water Level (WL) (mbsl) (independent) and predicted epilimnetic load of Total Dissolved Phosphorus (TDP) (t/Epilimnion) (dependent).

Other phytoplankton components not included in Table 1 are protozoa, bacteria, and zooplankton. The content of TN and TP in the epilimnetic loads (tones) and fractions comprising of TIN and TDP (tones) are shown in Table 2.

Data given in Table 2 indicates the higher portion of bio-available nitrogen and phosphorus (TIN, TDP) within the algal biomass in comparison with the Total fractions (TN, TP).

Fractional Polynomial Regression of the annual averages (1969-2001) were plotted and maximal and minimal values were taken from those figures to calculate the amplitude range of changes of Peridinium biomass (tones for the Epilimnion) and epilimnetic loads (tones/Epilimnion). Results are shown in Table 3. 


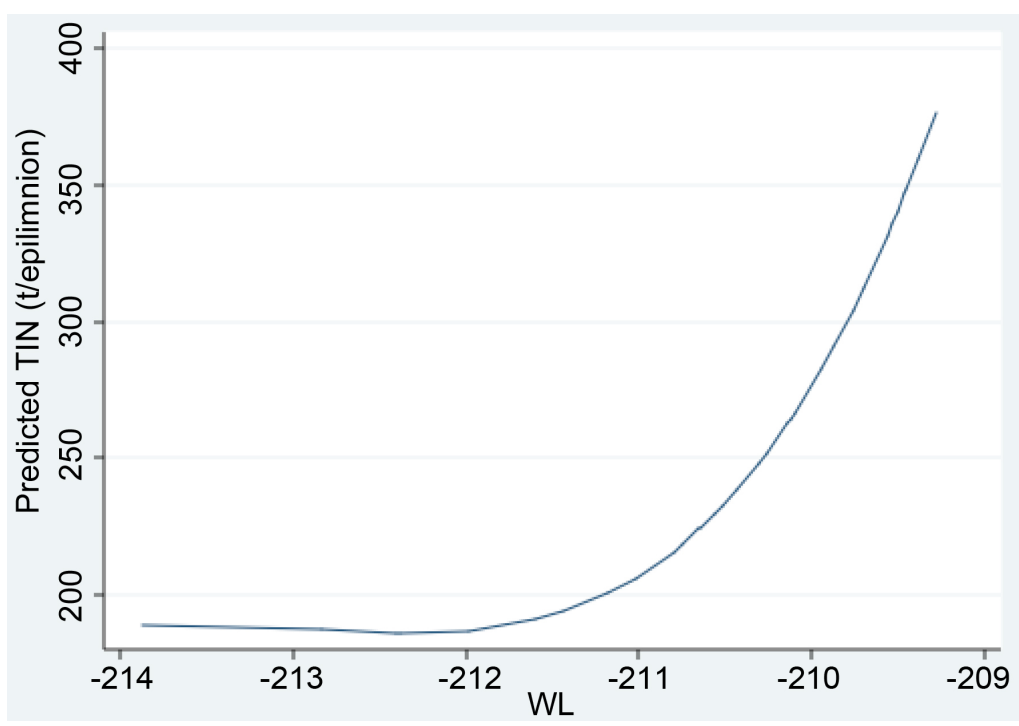

Figure 10. Fractional Polynomial Regression between annual means of Water Level (WL) (mbsl) (independent) and predicted Epilimnetic load of Total Inorganic Nitrogen (TIN) (t/Epilimnion) (dependent).

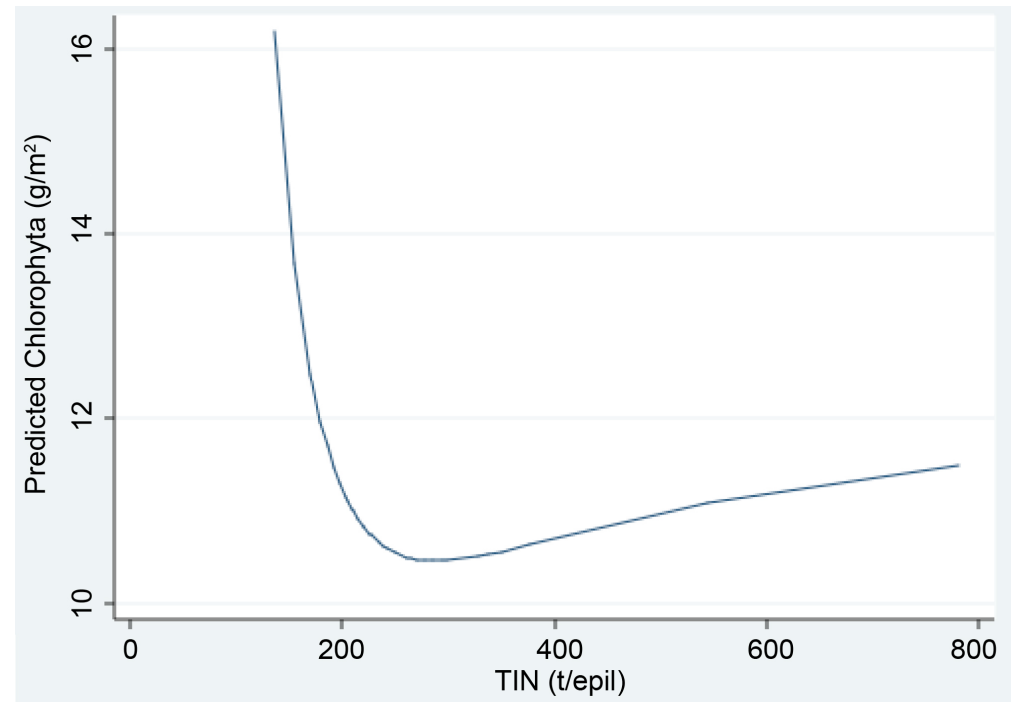

Figure 11. Fractional Polynomial Regression between annual means of Total Inorganic Nitrogen (TIN) epilimnetic loads (t/epilimnion) (independent) and predicted biomass $\left(\mathrm{g} / \mathrm{m}^{2}\right)$ of Chlorophyta (dependent).

The decline of epilimnetic TN and TP increase is prominent. However, the increase of Peridinium biomass in relation to TP load and concentration and vice versa with nitrogen is prominently specified. Also, the temporal decline of TIN and TDP are also shown.

\subsection{N/P Mass Ratios}

Figure 19 represent the temporal decline of N/P mass ratio in the Epilimnion of Lake Kinneret. The follow-up of this decline by the enhancement of the biomass of Cyanobacteria is shown in Figure 20 [10] [11]. 


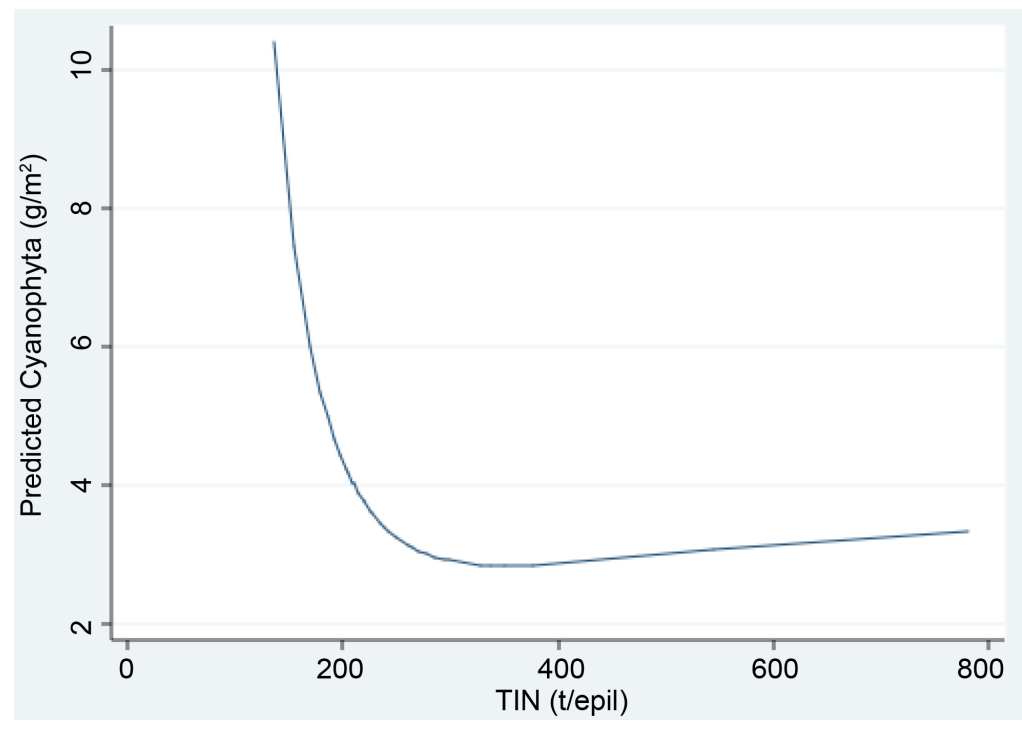

Figure 12. Fractional Polynomial Regression between annual means of Total Inorganic Nitrogen (TIN) epilimnetic loads (t/epilimnion) (independent) and predicted biomass $\left(\mathrm{g} / \mathrm{m}^{2}\right)$ of Cyanophyta (dependent).

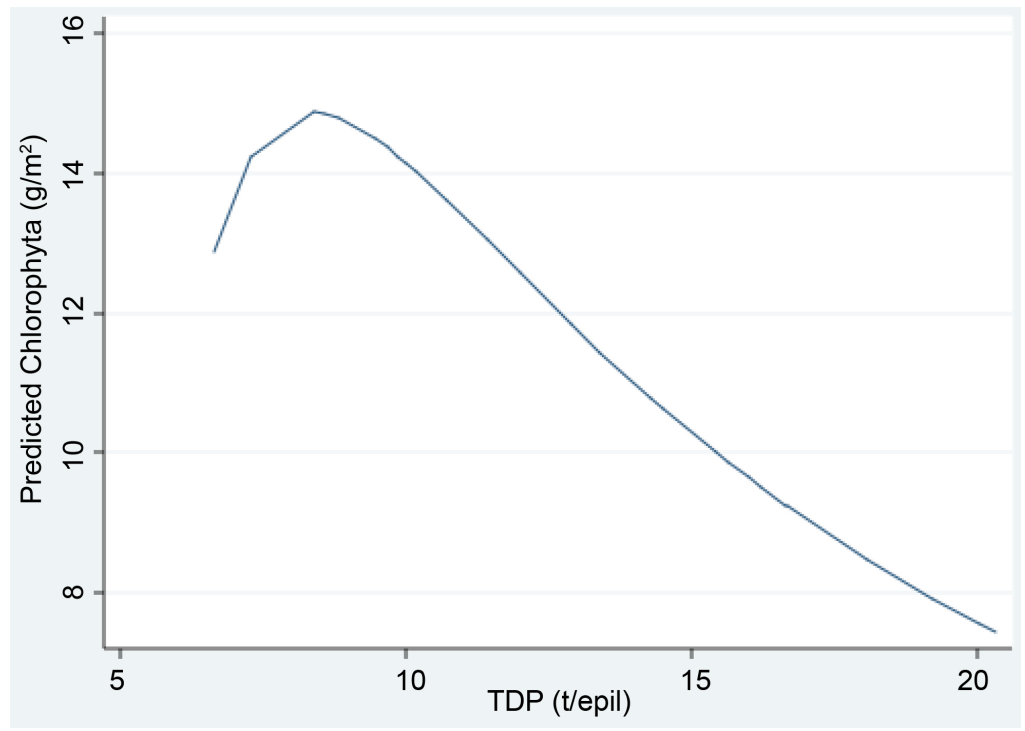

Figure 13. Fractional Polynomial Regression between annual means of Total Dissolved Phosphorus (TDP) epilimnetic loads ( $\mathrm{t} /$ epilimnion) (independent) and predicted biomass $\left(\mathrm{g} / \mathrm{m}^{2}\right)$ of Chlorophyta (dependent).

\section{Discussion}

The interrelationships between phytoplankton and nutrients were widely documented (among others) [4] [5] [6] [7]. Shifts from one to another algal group dominance was also widely documented [6] [7] [13] [14] [15] [16]. Experimental study of nutrient limitation for phytoplankton growth was quite often based on methodological approach of bioassay [7] [17] [18]. Nevertheless, the investigation of TN and TP content within the entire water column followed by TN/TP ratio indication is less common [10] [17] [19] [20]. The present study evaluates 


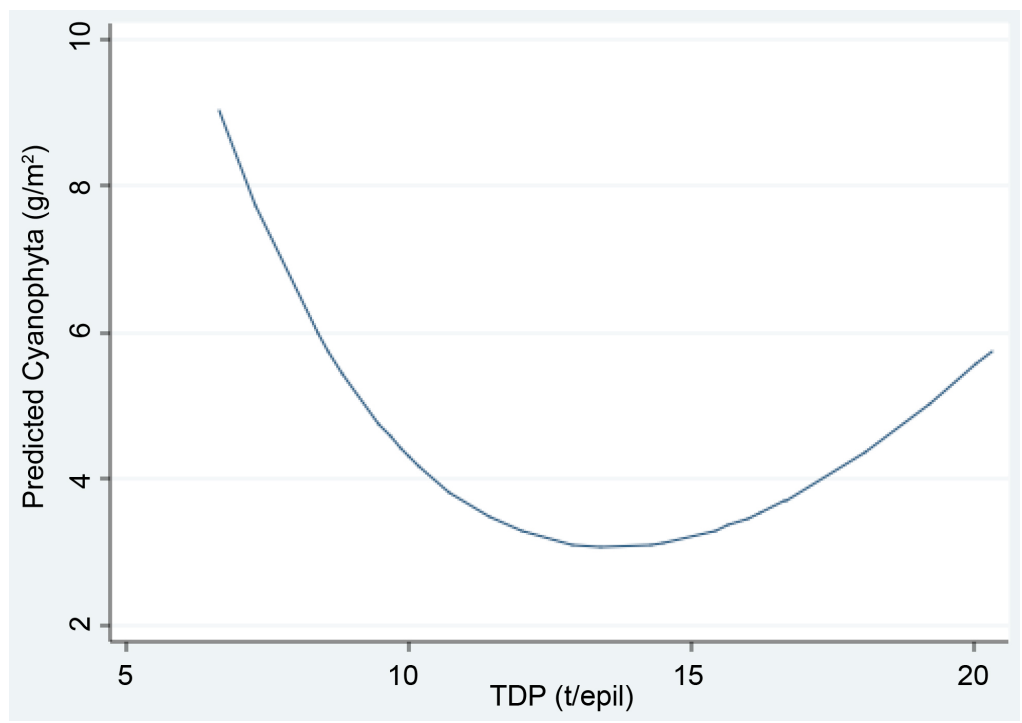

Figure 14. Fractional Polynomial Regression between annual means of Total Dissolved Phosphorus (TDP) epilimnetic loads (t/epilimnion) (independent) and predicted biomass $\left(\mathrm{g} / \mathrm{m}^{2}\right)$ of Cyanophyta (dependent).

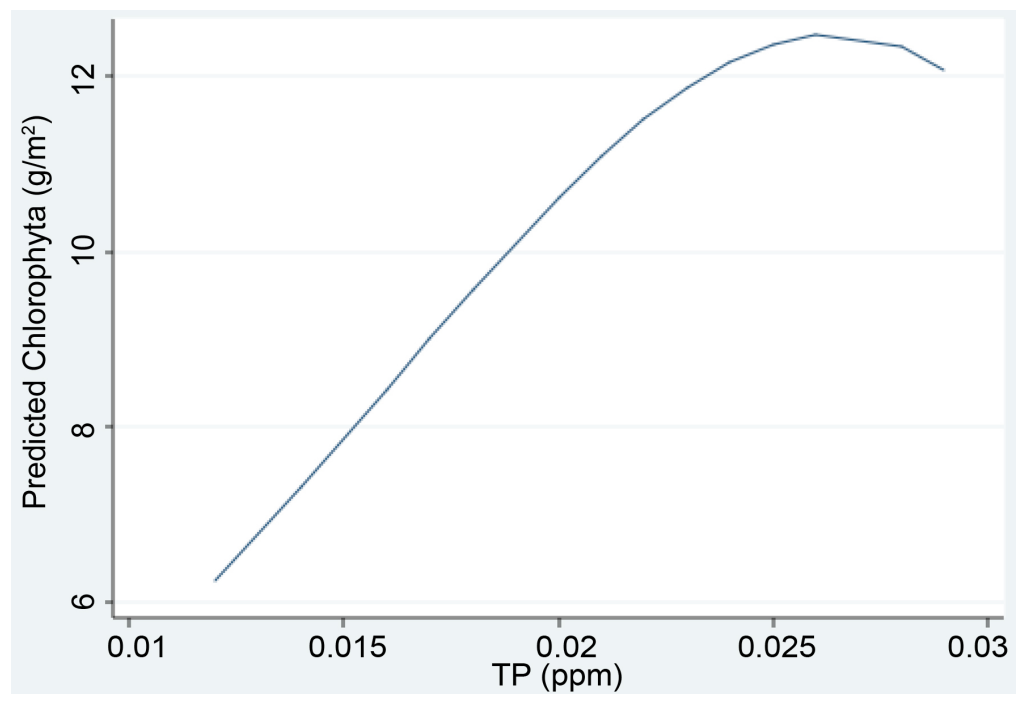

Figure 15. Fractional Polynomial Regression between annual means of epilimnetic Total Dissolved Phosphorus (TDP) Concentrations (ppm) (independent) and predicted biomass $\left(\mathrm{g} / \mathrm{m}^{2}\right)$ of Chlorophyta (dependent).

long-term field data set aimed at analyzing causation for the fluctuations of phytoplankton composition.

The TN and TP concentration is a measure of nutrient standing stock whilst TIN and TDP is an indication of bio-availability; i.e. the efficient portion of those two total nutrients for algal growth (Table 2). The nitrogen sources are mostly external in the Kinneret ecosystem and transported into the lake by water inflows. It is related both to the total standing stock (TN) and partly to the dissolved $\mathrm{N}$ species (TIN), therefore a direct positive regression exist between TN and TIN. Part of the TIN is possibly a product of TN microbial mineralization 


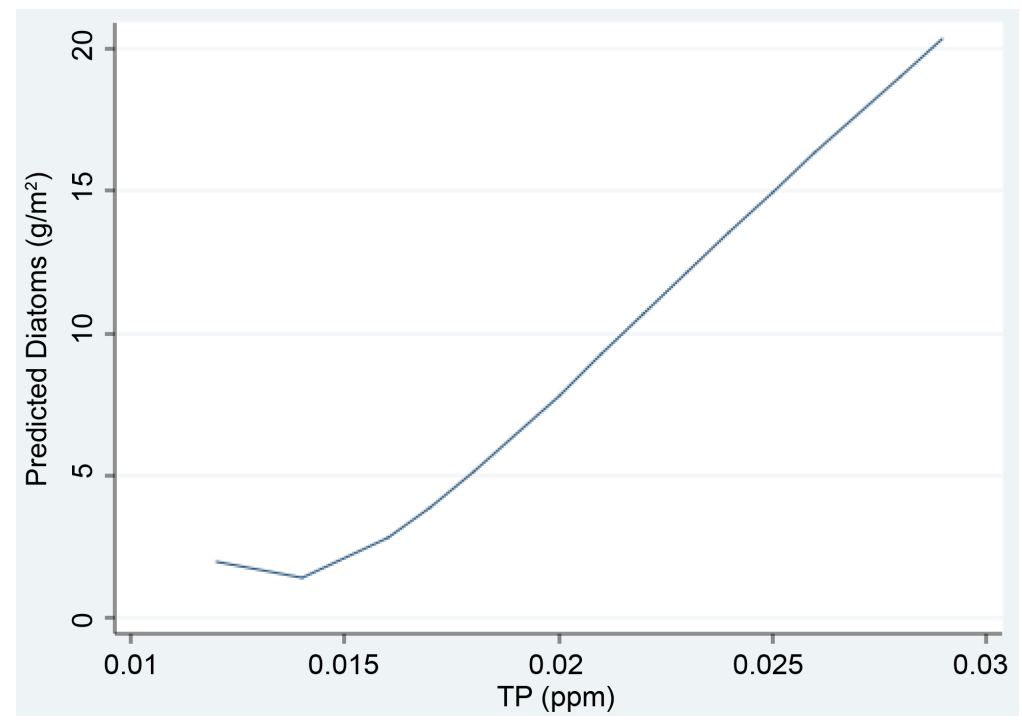

Figure 16. Fractional Polynomial Regression between annual means of epilimnetic Total Phosphorus (TP) Concentrations (ppm) (independent) and predicted biomass $\left(\mathrm{g} / \mathrm{m}^{2}\right)$ of Diatoms (dependent).

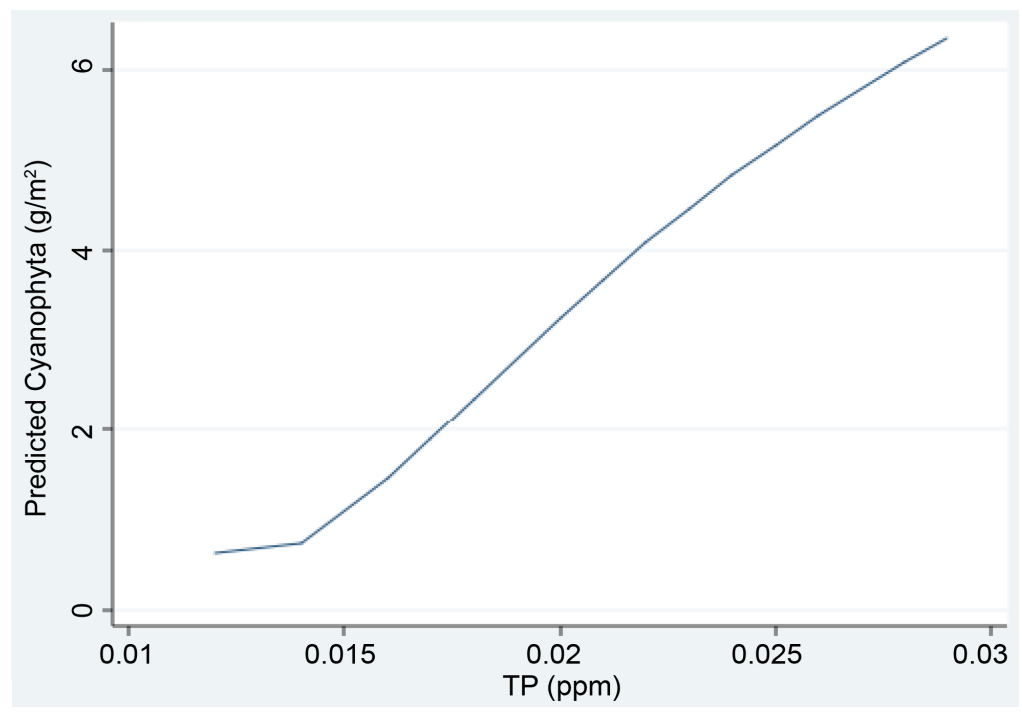

Figure 17. Fractional polynomial regression between annual means of epilimnetic Total Phosphorus (TP) Concentrations (ppm) (independent) and predicted biomass $\left(\mathrm{g} / \mathrm{m}^{2}\right)$ of Cyanophyta (dependent).

but within a close box which is fluxed from external sources. On the contrary, Kinneret sources of phosphorus are partly external (dust deposition and through water migration) and partly internal as microbial activity on sediments substrate and $\mathrm{P}$ mediated Peridinium cysts mineralization of the unlimited bottom sediments stock. The TP and TDP fluxes into the lake water are two independent processes and therefore the regression between them is not highly significant. The long term changes indicate decline of TIN, TDP and Peridinium in the lake. The TIN and partly TDP decrease $\left(r^{2}=0.2-0.3\right)$ was probably the result of Jordan River discharge decline which respectively decreased nutrients inputs. 


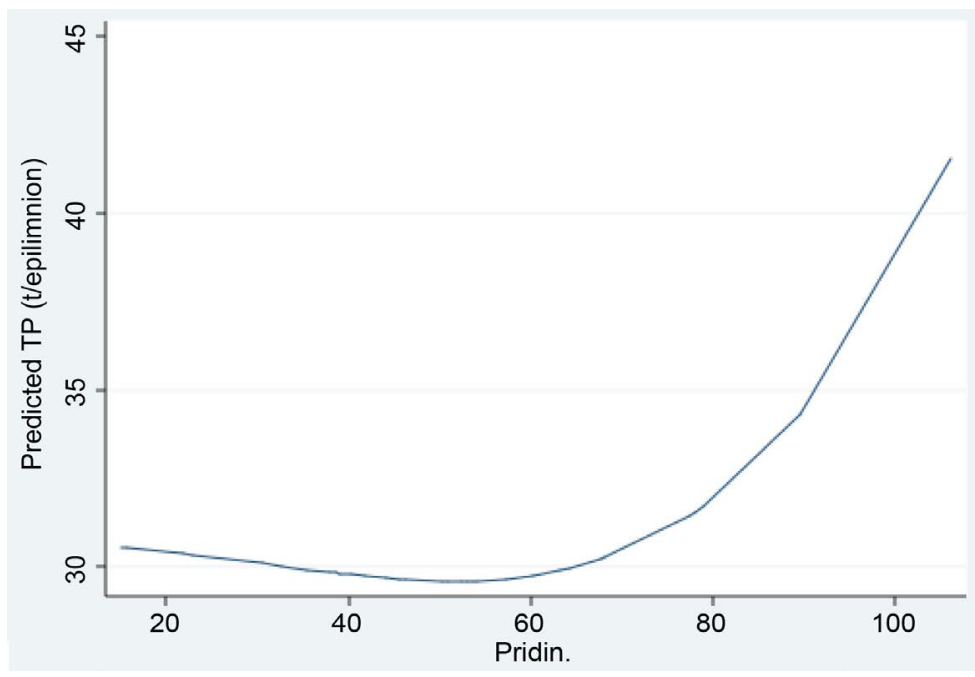

Figure 18. Fractional polynomial regression between peridinium biomass $\left(\mathrm{g} / \mathrm{m}^{2}\right)$ (independent) and predicted Total Phosphorus (TP) epilimnetic load (t/epilimnion) (dependent).

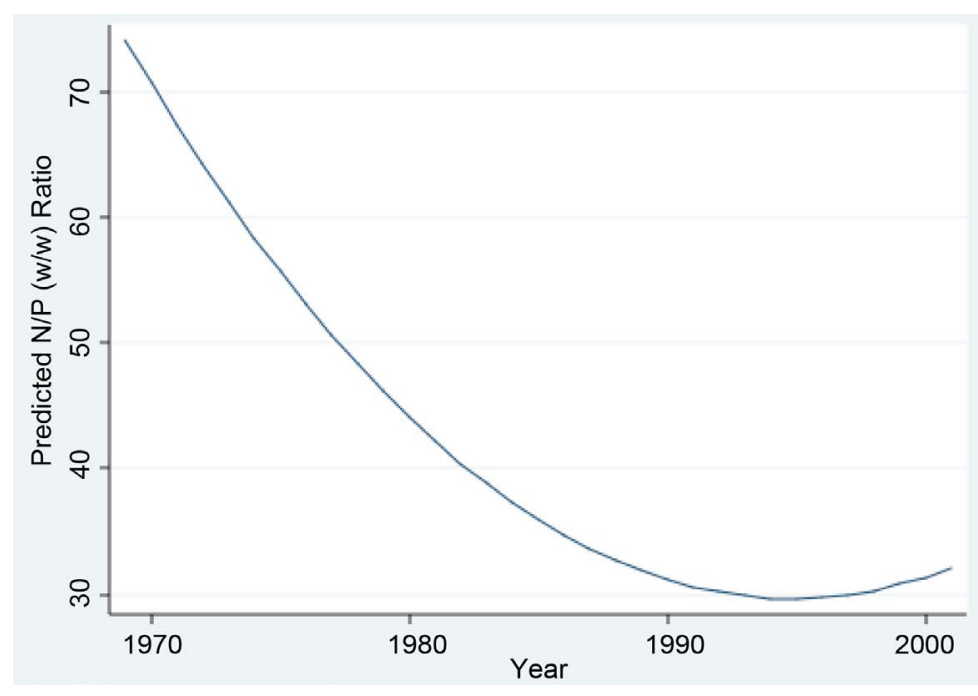

Figure 19. Temporal fractional polynomial regression between years (19692001) (independent) and predicted N/P (w/w) values (dependent).

Moreover, because nitrogen is a limiting factor for Peridinium growth and Peridinium cysts, mediated phosphorus, being lowered in, TDP content in the Kinneret Epilimnion was suppressed. Decline of Jordan River discharge was obviously accompanied by lake water level decline which was independently related to nutrient content decline as well as Peridinium (the major component of the total phytoplankton "box") decrease $\left(\mathrm{r}^{2}=0.5\right)$. Simple Linear Regression between monthly values of Jordan River Discharge and TN, TP and total phytoplankton were significantly positive: $\mathrm{r}^{2}=0.7-0.4, \mathrm{p}=0.0001-0.002$. Nonetheless, simple Linear regression between temporal data (years), and epilimnetic bio-available nutrient loads (TIN, TDP), Cyanophyta, Chlorophyta, diatoms, total phytoplankton represent positive relations (increase with time) whilst that 


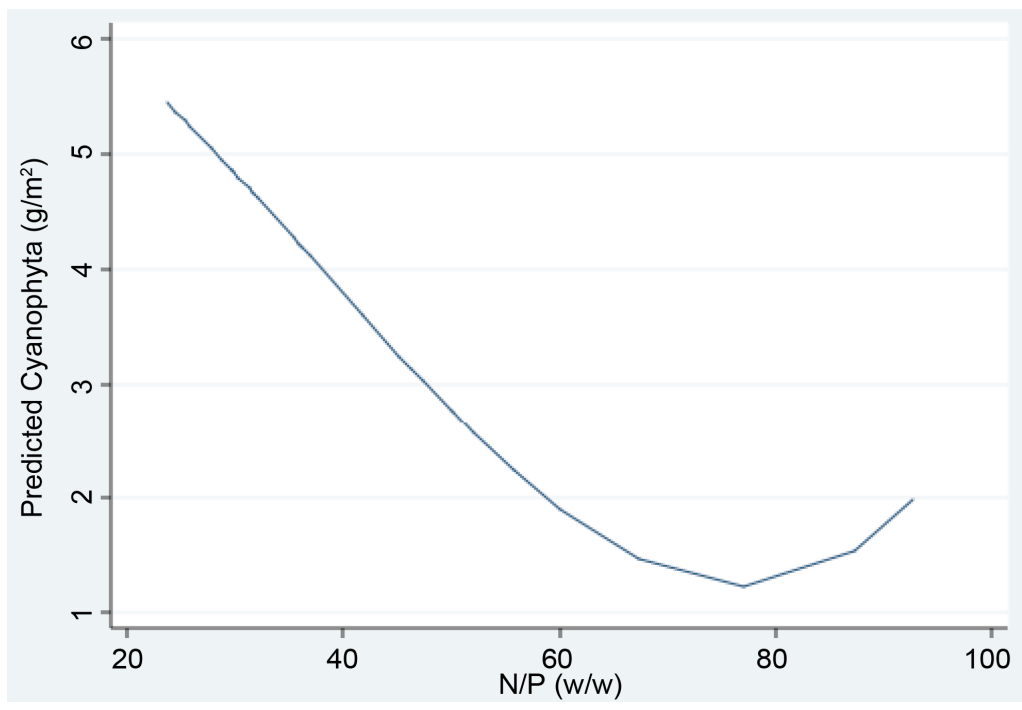

Figure 20. Fractional polynomial regression between N/P (w/w) Ratio (independent) and predicted cyanophyta biomass $\left(\mathrm{g} / \mathrm{m}^{2}\right)$ (dependent).

Table 1. Temporal (1969-2001) averages of the nitrogen and phosphorus epilimnetic loads within the phytoplankton components (cyanophyyta, diatoms, chlorophyta, peridinium) in Lake Kinneret: $\mathrm{g}(\mathrm{ww}) / \mathrm{m}^{2}$ multiplied by lake surface area $\left(168 \mathrm{~km}^{2}\right)$ converted to epilimnetic load (tones). Dry Weight $(\mathrm{dw})=40 \%$ of ww (wet weight); P content $=0.18 \%$ of $\mathrm{dw}$; $\mathrm{N}$ content $=3 \%$ of $\mathrm{dw}$ [8] [12].

\begin{tabular}{cccc}
\hline Algal group & $\mathbf{g}(\mathrm{ww}) / \mathrm{m}^{2}(\%)$ & $\begin{array}{c}\text { Nitrogen } \\
(\mathrm{t} / \text { Epilimnion) }\end{array}$ & $\begin{array}{c}\text { Phosphorus } \\
(\mathrm{t} / \text { Epilimnion) }\end{array}$ \\
\hline Cyanophytes & $3.96(4)$ & 7.98 & 0.48 \\
Diatoms & $8.68(8)$ & 17.50 & 1.05 \\
Chlorophytes & $11.14(11)$ & 22.46 & 1.35 \\
Peridinium & $51.62(52)$ & 104.70 & 6.24 \\
Total & 75.92 & 153.05 & 9.18 \\
\hline
\end{tabular}

Table 2. Periodical (1969-2001) averages of epilimnetic loads (tones/Epilimnion) of total phosphorus and nitrogen (TP, TN); bioavailable nitrogen and phosphorus (TIN, TDP) and \% included within the total phytoplankton in Lake Kinneret.

\begin{tabular}{ccc}
\hline Nutrient & t/Epilimnion & \% Within Phytoplankton \\
\hline TN & 1018 & 15 \\
TP & 30 & 30 \\
TIN & 267 & 57 \\
TDP & 13 & 71 \\
\hline
\end{tabular}

with Peridinium-the opposite, negative (decline with time). Actually, TN epilimnetic load decline was followed by increase of non-Peridinium algal biomass and vice versa (decline) in the Peridinium biomass. When epilimnetic TP load declined (Figure 18), Chlorophyta, and Cyanophyta biomass increased and that of diatoms and Peridinium declined. The water clarity factor is defined by Secchi depth (SEC) measurement: the deeper it is the water transparency is higher. 
Table 3. Maximal changes of peridinium biomass $\left(\mathrm{g} / \mathrm{m}^{2}\right)$ and epilimnetic nutrient loads (Nutrientas concentration (ppm) or load (t/Epilimnion) during 1969-2001 (TDP from 1974) as evaluated from Fractional Polynomial regressions. D = Decline; I = Increase; Lake Surface area $=168 \mathrm{~km}^{2}\left(=168 \times 10^{6} \mathrm{~m}^{2}\right)$ and Epilimnion Volume $=2000 \mathrm{mcm}$ (=million cubic meters; $\left.2000 \times 10^{9} \mathrm{~L}\right)$.

\begin{tabular}{|c|c|c|c|c|}
\hline $\begin{array}{l}\text { Dependant } \\
\text { variable }\end{array}$ & $\begin{array}{l}\text { Independent } \\
\text { variable }\end{array}$ & $\begin{array}{c}\text { Amplitude } \\
\text { (Values range) }\end{array}$ & Difference & $\begin{array}{l}\text { tones in the } \\
\text { epilimnion }\end{array}$ \\
\hline $\mathrm{TN}(\mathrm{ppm})$ & Year & $0.55-0.87(\mathrm{ppm})$ & $0.32(\mathrm{ppm})$ & $640 \mathrm{D}$ \\
\hline $\mathrm{TP}(\mathrm{ppm})$ & Year & $\begin{array}{c}0.016-0.024 \\
(\mathrm{ppm})\end{array}$ & $0.008(\mathrm{ppm})$ & $14 \mathrm{I}$ \\
\hline $\begin{array}{l}\text { Peridinium } \\
\left(\mathrm{g} / \mathrm{m}^{2}\right)\end{array}$ & $\mathrm{TP}(\mathrm{ppm})$ & $\begin{array}{c}50-90\left(\mathrm{~g} / \mathrm{m}^{2}\right) \\
0.02-0.03(\mathrm{ppm})\end{array}$ & $\begin{array}{c}40\left(\mathrm{~g} / \mathrm{m}^{2}\right) \\
0.01(\mathrm{ppm})\end{array}$ & $\begin{array}{l}6720 \mathrm{I} \\
20 \mathrm{I}\end{array}$ \\
\hline $\begin{array}{l}\text { Peridinium } \\
\quad\left(\mathrm{g} / \mathrm{m}^{2}\right)\end{array}$ & TN (t/epil) & $\begin{array}{c}10-130\left(\mathrm{~g} / \mathrm{m}^{2}\right) \\
3000-500 \\
\text { (t/Epil. })\end{array}$ & $\begin{array}{c}120\left(\mathrm{~g} / \mathrm{m}^{2}\right) \\
2500(\mathrm{t} / \text { Epil. })\end{array}$ & $\begin{array}{c}20,160 \mathrm{D} \\
2500 \mathrm{D}\end{array}$ \\
\hline TIN (t/Epil) & Year & 290 - 205 (t/Epil.) & 85 (t/Epil.) & $85 \mathrm{D}$ \\
\hline TDP (t/Epil) & Year (from 1974) & $17-7(\mathrm{t} /$ Epil $)$ & $10(\mathrm{t} /$ Epil $)$ & $10 \mathrm{D}$ \\
\hline
\end{tabular}

Figure 6 indicates an increase of SEC since early 1980s. Before the 1980s, Peridinium was heavily bloomed and resulted in shallowest SEC. After the disappearance of Peridinium, the non-Peridinium algal population dominated community, formed high water clarity, in which SEC was deepening (Figure 6). The inverse relation between Peridinium and Cyanophyte biomass density is prominently presented in Figure 7.

Including the water level (WL) parameter in the complex interactions between nutrients and algal community looks like being an "outsider" factor although ecological approach makes its integration justified. Figure 8 indicates WL decline since early 1980s. Moreover, Figure 9 and Figure 10 present the inverse relation between TDP, TIN and WL respectively. Obviously, the smaller the Jordan discharge, the lower is the WL and the lower are nutrient inputs. Nevertheless, decline of nutrient inputs lowered nitrogen supply which is demanded by Peridinium (Table 3) for normal growth rate. Consequently, decline of cysts mediated phosphorus supply, which has no interference to microbial and dust deposition of $\mathrm{P}$ fluxes, and therefore increases relative to nitrogen and non-Peridinium algae response, is being enhanced. The advantage of $\mathrm{N}_{2}$-fixation by Cyanophytes is clearly presented in Figure 12, as a prominent biomass enhancement under TIN deficiency. Epilimnetic TDP sources are partly Peridinium cysts mediated (In addition to dust deposition and sediment microbial activity) and the decline of Peridinium [1] opened the Epilimnion space free for other algal growth (Figure 13 and Figure 14). It is also shown in Figures 15-17 as non-Peridinium biomass enhancement related to decline of Peridinium biomass which is correlated with the decline of TP loads in the Epilimnion (see also Table 1). The reason for the Peridinium decline was nitrogen deficiency as presented in Figure 19 and Figure 20, as there was a temporal decline of nitrogen 
and the increase of Cyanophtes, respectively.

\section{Conclusion and Recommendation}

Long-term data set of phytoplankton biomass, TN, TP, TIN, and TDP nutrient loads and concentrations in the Epilimnion of Lake Kinneret indicate decline of nitrogen, and a slight increase of phosphorus. Those changes initiated decline of Peridinium and enhancement of non-Peridinium algal biomass. The events sequence is briefed as follows: Climate changes, temperature increase [21], and precipitation reduction as well as Jordan River discharge decline together with nitrogen removal in the drainage basin yielding lowered lake water level and nitrogen inputs. It also results in nitrogen decline and limitation for Peridinium and consequently decline of phosphorus fluxes into the Epilimnion through Cysts mediated phosphorus [22]. In addition, it results in Chlorophyta, Cyanophyta and diatoms growth rates enhancement partly as a result of absence of competition with Peridinium. Future management perspective suggests reappearance of Peridinium under present climate change, accompanied by declining Cyanobacteria by enhancement of nitrogen load in the Epilimnion together with suppression of phosphorus external inputs.

\section{References}

[1] Zohary, T (2004) Changes of the Phytoplankton Assemblage of Lake Kinneret after Decades of a Predictable Repetitive Pattern. Freshwater Biology, 49, 1355-1371. https://doi.org/10.1111/j.1365-2427.2004.01271.x

[2] Hoebell, E.A. (1972) The Study of Man. 4th Edition, McGraw Hill, New-York, 8.

[3] Mead, M. (1928) Coming to Age in Samoa. New York Perennial Classics, ISBN 978-0688050337, New York.

[4] Dzialowski, A.R., Wang, S.H., Lim, N.C., Spotts, W.W. and Huggins, D.G. (2005) Nutrient Limitation of Phytoplankton Growth in Central Plains Reservoirs, USA. Journal of Plankton Research, 27, 587-595. https://doi.org/10.1093/plankt/fbi034

[5] Hecky, R.E. and Kilham, P. (1988) Nutrient Limitation of Phytoplankton in Freshwater and Marine Environment: A Review of Recent Evidence on the Effects of Enrichment. Limnology and Oceanography, 33, 796-822.

[6] Smith, V.H. (2003) Eutrophication of Freshwater and Coastal Marine Ecosystems: A Global Problem. Environmental Science and Pollution Research, 10, 126-139. https://doi.org/10.1065/espr2002.12.142

[7] Elser, J.J., Marzolf, E.R. and Goldman, C.R. (1990) Phosphorus and Nitrogen Limitation of Phytoplankton Growth in the Freshwaters of North America: A Review and Critique of Experimental Enrichment. Canadian Journal of Fisheries and Aquatic Sciences, 47, 1468-1477. https://doi.org/10.1139/f90-165

[8] LKDB-KLL Lake Kinneret Data-Base (1969) Kinneret Limnological Laboratory, IOLR, Annual Reports (M. Schlichter: Data Compilation and Computerization), Chapters: Phytoplankton (U. Pollingher, and T. Zohary) and Water Chemistry (C. Serruya and A. Nishri), LKDB-KLL Lake Kinneret Data-Base. (in Hebrew)

[9] Gophen, M. (2017) Fish-Zooplankton-A Predator-Prey Relations as a Key Factor for the Design of Zooplankton Distribution Sampling Program in Lake Kinneret, Israel. Open Journal of Modern Hydrology, 7, 209-222. 
https://doi.org/10.4236/ojmh.2017.73012

[10] Guildford, S.J., Hecky, R.E. (2000) Total Nitrogen, Total Phosphorus and Nutrient Limitation in Lakes and Oceans: Is There a Common Relationship? Limnology and Oceanography, 45, 1213-1223. https://doi.org/10.4319/lo.2000.45.6.1213

[11] Smith, V.H. and Bennett, S.J. (1999) Nitrogen: Phosphorus Supply Ratios and Phytoplankton Community in Lakes. Archiv für Hydrobiologie, 146, 37-53. https://doi.org/10.1127/archiv-hydrobiol/146/1999/37

[12] Berman, T. (1978) Chapter: General Biochemical Features. In: Serruya, C., Ed., Lake Kinneret Monographiae Biologicae, Vol. 32, Dr. W. Junk Publishers, The Hague, 269-271.

[13] Downing, J.A., Watson, S.B. and MvCouly, E. (1999) Predicting Cyanobacteria Dominance in Lakes. Canadian Journal of Fisheries and Aquatic Sciences, 46, 1905-1908.

[14] Saadoun, I.M., Schrader, K.K. and Blevins, E.T. (2001) Environmental and Nutritional Factors Affecting Geosmin Synthesis by Anabaena sp. Water Research, 35, 1209-1218.

[15] Smith, V.H., Sieber-Denlinger, J., deNoyelles, J., et al. (2002) Managing Taste and Odor Problems in a Eutrophic Drinking Water Reservoir. Lake and Reservoir Management, 18, 319-323. https://doi.org/10.1080/07438140209353938

[16] Maberly, S.C., King, L., Dent, M.M., et al. (2002) Nutrient Limitation of Phytoplankton and Periphyton Growth in Upland Lakes. Freshwater Biology, 47, 2136-2152. https://doi.org/10.1046/j.1365-2427.2002.00962.x

[17] Smith, V.H. (1998) Cultural Eutrophication of Inland, Estuarine, and Coastal Watrs. In: Pace, M.L. and Goffman, P.M., Eds., Limitation and Frontiers in Ecosystem Science, Springer-Verlag, New York, 7-49. https://doi.org/10.1007/978-1-4612-1724-4_2

[18] Mallin, M.A., Johnston, V.L. and Mclver, M.R. (2004) Nutrient Limitation and Algal Blooms in Urbanizing Tidal Creeks. Journal of Experimental Marine Biology and Ecology, 298, 211-231.

[19] Schelske, C.L., Aldrige, F.J. and Kenney, W.F. (1999) Assessing Nutrient Limitation and Trophic State in Florida Lakes. In: Reddy, K.R., OConnor, G.A. and Schelske, C.L., Eds., Phosphorus Biogeochemistry in Subtropical Ecosystems, Lewis Publishers, Boca Rotan, 321-342.

[20] Dodds, W.K. (2003) Misuse of Inorganic N and Soluble Reactive P Concentraqtions to Indicate Nutrient Status of Surface Waters. Journal of the North American Benthological Society, 22, 171-181. https://doi.org/10.2307/1467990

[21] Peter, K.H. and Sommer, U. (2015) Interactive Effect of Warming, Nitrogen and Phosphorus Limitation on Phytoplankton Cell Size. Ecology and Evolution, 5, 1011-1024. https://doi.org/10.1002/ece3.1241

[22] Muhid, P. and Burford, M.A. (2012) Assessing Nutrient Limitation in a Subtropical Reservoir. Inland Waters, 2, 185-192. https://doi.org/10.5268/IW-2.4.468

\section{Abbreviations}

TN, total nitrogen; TP, total phosphorus; TIN, total inorganic nitrogen; TDP, total dissolved phosphorus; WL, water level; mbsl, meter below sea level; $\mathrm{m}^{3} / \mathrm{s}$, Cubic Meter per Second. 